\title{
Vitamin D supplementation after the second year of life: joint position of the Committee on Nutrition, German Society for Pediatric and Adolescent Medicine (DGKJ e.V.), and the German Society for Pediatric Endocrinology and Diabetology (DGKED e.V.)
}

Thomas Reinehr ${ }^{1 \dagger}$, Dirk Schnabel ${ }^{2^{* \dagger}}$, Martin Wabitsch ${ }^{3}$, Susanne Bechtold-Dalla Pozza ${ }^{4}$, Christoph Bührer $^{5}$, Bettina Heidtmann ${ }^{6}$, Frank Jochum ${ }^{7}$, Thomas Kauth ${ }^{8}$, Antje Körner ${ }^{9}$, Walter Mihatsch ${ }^{10}$, Christine Prell', Silvia Rudloff ${ }^{11,14}$, Bettina Tittel ${ }^{12}$, Joachim Woelfle ${ }^{13}$, Klaus-Peter Zimmer $^{14}$ and Berthold Koletzko ${ }^{4^{*}}$

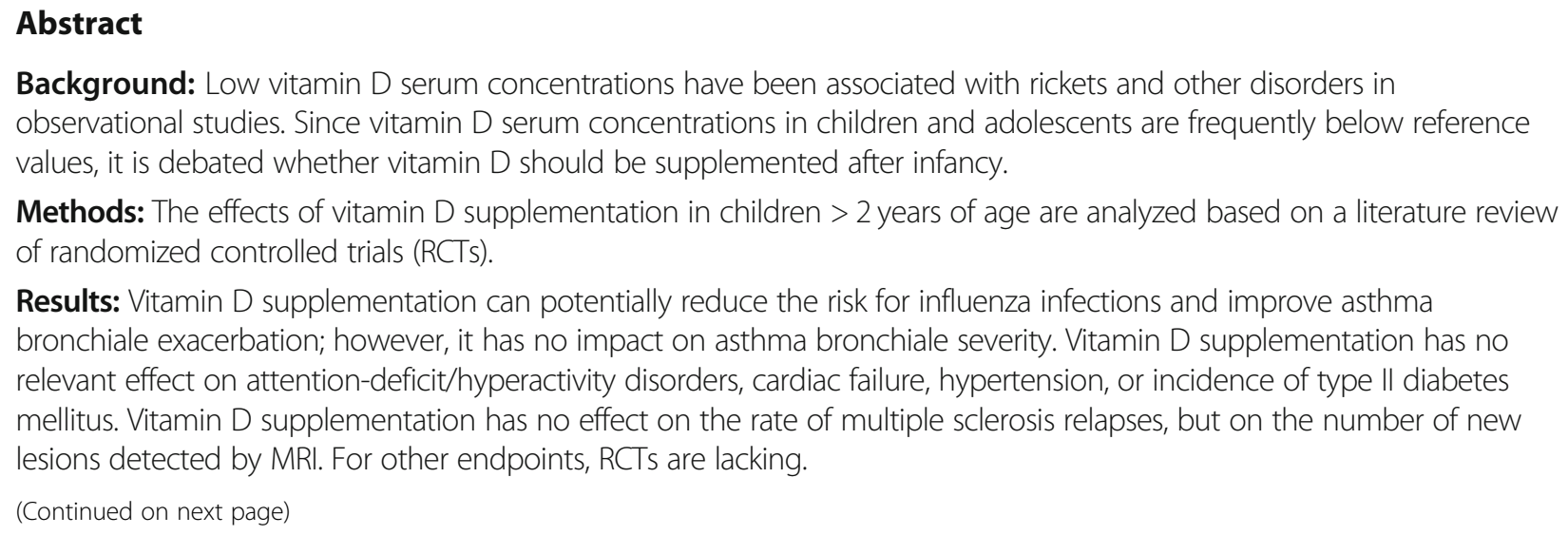

\footnotetext{
* Correspondence: dirk.schnabel@charite.de; info@dgkj.de;

Berthold.Koletzko@med.uni-muenchen.de

This article is a translation of T. Reinehr, D. Schnabel et al. (2018) Vitamin-D-

Supplementierung jenseits des zweiten Lebensjahres - Gemeinsame

Stellungnahme der Ernährungskommission der Deutschen Gesellschaft für

Kinder und Jugendmedizin (DGKJ e.V.) und der Deutschen Gesellschaft für Kinderendokrinologie und Diabetologie (DGKED e.V.), Monatsschr

Kinderheilkd 166:814-822 https://doi.org/10.1007/s00112-018-0502-6 [1]

${ }^{\dagger}$ Thomas Reinehr and Dirk Schnabel contributed equally to this work.

${ }^{2}$ Sozialpädiatrisches Zentrum für chronisch kranke Kinder, Charité

Universitätsmedizin Berlin, Berlin, Germany

${ }^{4}$ LMU, Ludwig-Maximilians-Universität München, Dr. von Hauner Children's

Hospital, Munich, Germany

Full list of author information is available at the end of the article
} 


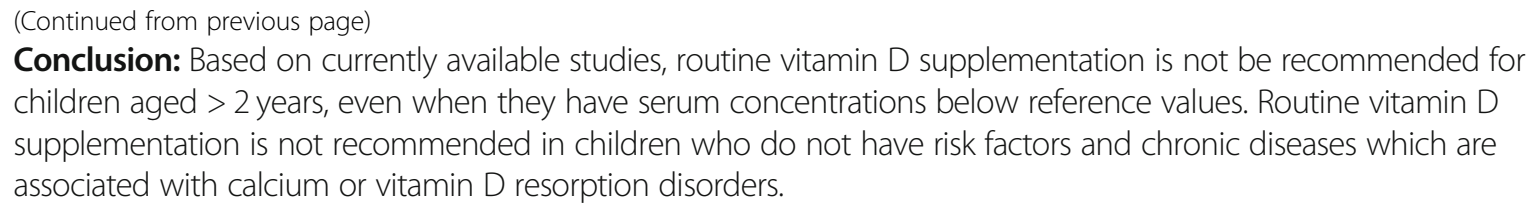

Keywords: Vitamin D supplementation, Infection, Asthma bronchiale, Hypertension, Obesity, Diabetes mellitus, Attentiondeficit/hyperactivity disorder

\section{Introduction}

The Committee on Nutrition, German Society for Pediatric and Adolescent Medicine, in collaboration with the Pediatric Endocrinology Working Group, wrote a position paper on vitamin D intakes in childhood in 2011 [1, 2]. Metabolism, effects, and intake recommendations for vitamin $\mathrm{D}$ were discussed, including the proposition that vitamin D provision promotes age-appropriate mineralization of the skeletal system and prevents the onset of rickets for the first 12-18 months (up until a child's second early summer) [3, 4]. It has also been shown [2] that subnormal vitamin D serum concentrations (see Table 1 for current definitions) are often measured in children over the age of two [5-8]. In this position statement, a total vitamin D intake of 600 IU/day (from sunlight-dependent self-synthesis and enteral intakes) is considered desirable [2]. The German Nutrition Society recommends a total vitamin D intake of $800 \mathrm{IU} /$ day starting from the age of two [9].

Since many children in Germany do not achieve desired vitamin D intake levels, it is debated whether and when vitamin D supplementation should take place beyond the first 12 to 18 months of life. Vitamin D not only positively affects the skeletal system but is also postulated to be preventative of inflammatory diseases, autoimmune diseases such as type I diabetes, attention-deficit/hyperactivity disorder, asthma bronchiale, multiple sclerosis, cancers, and lifestyle-related diseases such as obesity, type II diabetes, hypertension, and heart failure [3, 10-14]. However, vitamin D supplementation in children over the age of 2 years of age, even at low vitamin D serum levels, is becoming increasingly controversial $[5,10,12-14]$. Adverse reactions from adequately dosed vitamin D supplements (e.g., 600$800 \mathrm{IU} /$ day) are unlikely, as vitamin D has a broad therapeutic index $[2,3]$. However, to make a population-wide

Table 1 Recommended limits for vitamin D serum concentrations (25-OH vitamin D) [3]

$$
\begin{aligned}
& \cdot>100 \mathrm{ng} / \mathrm{mL}(>250 \mathrm{nmol} / \mathrm{L}): \text { intoxication } \\
& \cdot 20-100 \mathrm{ng} / \mathrm{mL}(50-250 \mathrm{nmol} / \mathrm{L}): \text { target area } \\
& \cdot 12-20 \mathrm{ng} / \mathrm{mL}(30-50 \mathrm{nmol} / \mathrm{L}): \text { subnormal } \\
& \cdot<12 \mathrm{ng} / \mathrm{mL}(<30 \mathrm{nmol} / \mathrm{L}) \text { : deficiency }
\end{aligned}
$$

recommendation for vitamin D supplementation in childhood and adolescence, a proven benefit should preferably be demonstrated in randomized controlled intervention trials. In addition, existing studies on the relationship between vitamin $\mathrm{D}$ and health outcomes must be interpreted together with knowledge of the physiology of vitamin D metabolism, the vitamin D supply in Germany, the possibility of errors in the measurement of vitamin $\mathrm{D}$, and the background of the existing vitamin $\mathrm{D}$ target values.

Given the ongoing discussion on when and which children and adolescents should receive vitamin D supplementation after the second year of life, recommendations for vitamin $\mathrm{D}$ supplementation for this age range have been updated based on a literature review of randomized controlled trials.

\section{Physiology of vitamin D metabolism}

Up to $90 \%$ of the body's daily vitamin D requirement is covered by solar radiation (UV-B radiation). The extent of vitamin $\mathrm{D}$ synthesis depends on the time of day and the season of the year. Due to Germany's geographic location (between 48 and $54^{\circ}$ northern latitude), UV-B radiation between 10:00 am and 3:00 pm between the months of April and September is sufficient for vitamin D synthesis. However, this is true only if the head and forearms are exposed to the sun without sunscreen for a daily average of about 10-15 min, which is dependent on skin type (skin pigmentation) [2].

About $10 \%$ of required vitamin $\mathrm{D}$ can be ingested through food. In particular, sea fish such as eel, herring, mackerel, and salmon show relatively high vitamin D contents. From vitamin, $25-\mathrm{OH}$ vitamin $\mathrm{D}$ and subsequent calcitriol $\left(1,25(\mathrm{OH})_{2}\right.$ vitamin $\left.\mathrm{D}\right)$ are formed via hydroxylation steps in the liver and then in the kidney. Calcitriol regulates calcium and phosphate metabolism and increases the mineralization of the bone.

Vitamin D deficiency leads to calcium deficiency, which results from reduced calcium absorption in the intestine. Low calcium levels in turn lead to an increased parathyroid hormone secretory response. Parathyroid hormone, on the other hand, increases serum calcium levels by increasing the release of calcium from bone and by decreasing 
calcium excretion into the urine. Rickets manifests itself especially when the daily calcium intake is also low [3].

However, vitamin D not only regulates calcium and phosphate metabolism and thus skeletal mineralization, but also shows multiple modulatory properties in animal experiments, especially on the immune system [15]. Vitamin D regulates more than 300 genes in the mouse model, and the expression of the vitamin $\mathrm{D}$ receptor has been detected in about 40 tissues so far [16]. In animal models, after the binding of an infectious agent to the toll-like macrophage receptor, the increased CYP27B1 enzyme stimulation leads to an increased formation of calcitriol. Upon binding to the vitamin D receptor, the formation of cathelicidin and $\beta$-defensin 2 is stimulated. Through antiviral, respectively, antibacterial activity, the agent is destroyed [17, 18]. Therefore, it is postulated that vitamin $\mathrm{D}$ deficiency could promote the occurrence of autoimmune diseases as well as an increased susceptibility to infections in humans [15].

\section{Laboratory assessment of vitamin D}

Biochemically, vitamin D is a steroid hormone and is as difficult and expensive to determine as testosterone and estradiol. Assessment of vitamin D status is usually conducted by measuring the serum $25-\mathrm{OH}$ vitamin $\mathrm{D}$ concentration. The gold standard is HPLC or LC/MS methods and not ELISA, which is the most commonly used method in large laboratories [19]. The advantage of chromatographic or spectrometric methods lies in the high specificity of the detection of vitamin $\mathrm{D}$, whereas in immunoassays, it is very dependent on the antibodies and standards used. To date, there is no internationally recognized standard for vitamin $\mathrm{D}$ assessment. Vitamin $\mathrm{D}$ is labile to light, so serum tubes must be stored and shipped away from light to avoid false low readings.

\section{Vitamin D supply in Germany}

In the DONALD cohort study, $80 \%$ of children aged 1 to 12 years had dietary vitamin D intakes lower than recommended by the German Nutrition Society, based on 3-day dietary protocols [9]. The KIGGS study, which is representative of German children, showed that only $36.1 \%$ of children had a vitamin $\mathrm{D}$ serum concentration within the target range (see Table 1). Deficiencies were particularly common in winter and spring, in obese children, in children with low physical activity, in children from socially disadvantaged backgrounds, and in children with a migrant background $[6,7]$. The high prevalence of vitamin D serum levels below the target range was also confirmed in measurements using the more accurate HPLC method [20].

Low vitamin D serum levels are not only found in Germany but also in other European countries. In a study of 131 healthy adolescents aged $12-15$ years in Manchester, more than two thirds of children had vitamin $\mathrm{D}$ serum concentrations below the target range in winter and spring and more than one third in summer and autumn [8].

\section{Interpretation of serum vitamin D levels}

Despite the high prevalence of vitamin D serum levels below the target range, overt rickets in infants and adolescents beyond infancy and in the absence of other risk factors (see Table 2) is rare. The recommended target level for vitamin $\mathrm{D}$ in children (Table 1) is not adapted for age, gender, or season. If target values were calculated solely based on the statistical distribution of published vitamin D serum concentrations in healthy children and adolescents determined by HPLC, the third percentile would be $8 \mathrm{ng} / \mathrm{mL}$ in winter and spring and $14 \mathrm{ng} / \mathrm{mL}$ in summer and autumn [8]. However, one cannot conclude that vitamin D concentrations above the third percentile of the distribution achieve adequate health effects.

The recommended vitamin $\mathrm{D}$ target values are not based on the normal distribution of apparently healthy populations. Target values are based on considering vitamin $\mathrm{D}$ serum levels at which sufficient calcium is absorbed [13, 21, 22]. Considering only enteral vitamin $D$ intakes, healthy people aged 1-70 years of age need a daily intake of $400 \mathrm{IU}$ (estimated average requirement [EAR]), with a mean serum vitamin D level of $16 \mathrm{ng} / \mathrm{mL}$.

In order to ensure adequate provision in almost all individuals in a population, a threshold based on the mean plus two standard deviations of the distribution is established, according to the general concepts of nutrient reference levels [23] (see Fig. 1). This results in a targeted vitamin D serum level of $20 \mathrm{ng} / \mathrm{mL}(50 \mathrm{nmol} / \mathrm{L})$, which corresponds to the Recommended Dietary Allowance (RDA) or the Population Reference Intake (PRI) [24]. However, this limit also implies that many people below this vitamin D level still have adequate calcium

Table 2 Pediatric populations at increased risk for vitamin D deficiency

- Exclusively breastfed infants without vitamin D prophylaxis
- Infants, children, and adolescents with:
- Malabsorption or maldigestion disorders (e.g., celiac disease, Crohn's
disease, cystic fibrosis)
- Chronic inflammatory diseases (e.g., inflammatory bowel disease)
- Chronic kidney disease
- Chronic liver disease
- On permanent medication with substances that affect calcium or
vitamin D metabolism (e.g., antiepileptic drugs, antiviral medication,
fungicides, or high dose glucocorticoid therapy which inhibits
intestinal calcium absorption and stimulates tubular calcium excretion)
- With very low sun exposure, for example, chronically immobilized
children and adolescents
- With a migrant background (through the influence of pigmentation,
nutrition, and sun exposure)




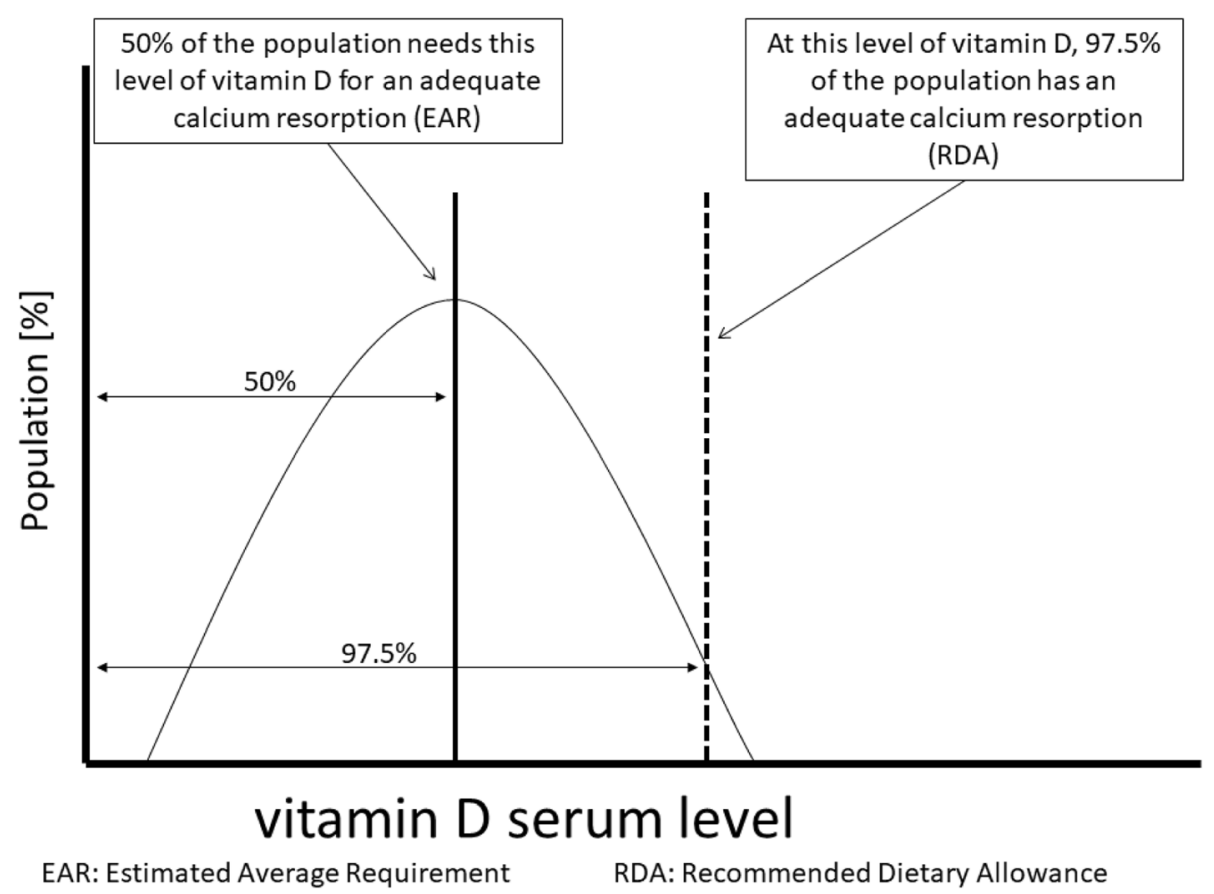

Fig. 1 Distribution of vitamin D serum concentrations to ensure adequate calcium absorption in a healthy population and the resulting limits in the absence of sun exposure (figure adapted according to [13])

absorption [13]. This explains, among other things, why a majority of children with vitamin D serum levels below the target level or even vitamin D deficiency as defined in Table 1 do not develop rickets or apparent alterations in bone mineralization, and only a fraction of these children and adolescents show secondary hyperparathyroidism. In addition, a calcium intake of $>500 \mathrm{mg}$ /day may prevent the manifestation of rickets and subnormal bone mineralization, even at low vitamin D levels [1]. Individual vitamin $\mathrm{D}$ therapy is indicated if, in addition to a reduced vitamin D (25-OH vitamin D) concentration, secondary hyperparathyroidism and/or radiologically confirmed rickets are present $[3,5]$. A vitamin D serum level below $20 \mathrm{ng} / \mathrm{mL}$ does not have any definite pathological significance on its own without the existence of further risk factors [5].

\section{Vitamin D and skeletal diseases}

Rickets, as a vitamin D deficiency disease, as well as its diagnosis and therapy, is discussed in the position statement of DGKJ from 2011 [1, 2] and in international recommendations [3]. In addition to rickets, associations between bone density and vitamin D are also discussed. However, associations alone do not prove causal relationships. For example, the Young Heart 2000 study [25] showed significantly higher forearm bone density at normal vitamin D serum levels in adolescent girls aged 12 to 15 than in girls with vitamin $\mathrm{D}$ concentrations below target. In boys, this association was not found. Secondary data analysis revealed that girls' forearm density was closely associated with cardio-respiratory fitness, which in turn was related to outdoor exercise [26]. Thus, the association between low vitamin D serum levels and forearm bone density could also be indirectly related to outdoor exercise. A low serum level of the "sunshine hormone" vitamin D could be a marker for lack of activity outdoors. This fact also limits the possible deductions from a study describing an association between vitamin D serum concentrations and bone density in adolescent girls [27]. Increased outdoor activity may have positively influenced both vitamin D serum levels and bone mineral density. In fact, the same authors conclude that increased physical activity increases bone density [28]. In a randomized controlled trial, however, a positive effect of vitamin $\mathrm{D}$ on the bone density of girls could be demonstrated. This effect was no longer statistically significant in an intention-to-treat analysis including girls who did not take the vitamin D supplement on a regular basis [29]. It was concluded from meta-analyses of placebo-controlled trials that vitamin D supplementation in healthy children does not improve bone density, but may have positive effects in children with vitamin D serum concentrations below target [30, 31].

\section{Vitamin D and extraskeletal diseases}

Vitamin D deficiency is not only associated with skeletal disorders [3], but also with various other diseases [15] (see Table 3). Most of the postulated correlations are based on association studies or epidemiological studies. 
Table 3 Pediatric and adolescent diseases that were postulated to be associated with vitamin D serum concentrations due to their associations in observational studies

\begin{tabular}{lll}
\hline & References & Effect of vitamin D supplementation from RCTs \\
\hline Diseases of the upper airway & {$[10,14,37-40,51]$} & + and - \\
Asthma bronchiale & {$[36,52,53]$} & + and - \\
Attention-deficit/hyperactivity disorder & {$[54-56]$} & - \\
Type I diabetes mellitus & {$[10,14,32-35]$} & No RCT performed \\
Type II diabetes mellitus & {$[10,14,44-50]$} & + and - \\
High blood pressure & {$[10,14,41,43]$} & - \\
Cardiac insufficiency & {$[10,14]$} & No RCT performed \\
Obesity & {$[10,11,14,57-59]$} & + and -* \\
Multiple sclerosis & {$[60-63]$} &
\end{tabular}

$R C T$ randomized controlled trials, + RCT showed a positive effect from vitamin D supplementation on the studied parameter, $-\mathrm{RCT}$ showed no effect from vitamin D supplementation on the studied parameter

*Vitamin D had no effect on the frequency of multiple sclerosis relapses but a positive effect on the number of sclera on MRI

Controlled randomized intervention studies are often lacking or fail to show any effect of vitamin D on the respective diseases examined in the case of the few available intervention studies (see Table 3).

Another example of the difficulties in interpreting association studies is the postulated association between vitamin $\mathrm{D}$ and the prevalence of type I diabetes mellitus (T1DM). In Finland, a dose reduction of vitamin D supplementation from $2000 \mathrm{IU} /$ day in 1965 to $400 \mathrm{IU} /$ day in 1995 was associated with an increased prevalence of T1DM with [32]. No further increase in T1DM incidence occurred since 2006 [33]. Therefore, it was postulated that vitamin $\mathrm{D}$ supplementation could reduce the risk of developing T1DM by up to 30\% [34]. However, serum vitamin D levels before initiation of seroconversion of islet cell autoantibodies or prior to manifestation of T1DM did not differ from those in children who did not have T1DM and had no islet cell autoantibodies [35]. This suggests that a causal relationship between vitamin $\mathrm{D}$ serum concentrations and the risk of developing T1DM is questionable.

A positive effect of vitamin D supplementation on childhood asthma bronchiale was shown in randomized controlled trials. Vitamin D supplementation in children with asthma bronchiale has led to a significant reduction in asthma bronchiale exacerbations and the frequency of inpatient hospital admission in children with mild asthma bronchiale [36]. However, the forced expiratory volume in one second (FEV1) as a measure of disease severity did not improve with vitamin $\mathrm{D}$ supplementation in randomized controlled trials [36].

The effect of vitamin D on asthma bronchiale is attributed to a reduction in the frequency of acute upper respiratory infections [36]. In a randomized controlled trial, 169 children aged 6 to 12 years received $1200 \mathrm{IU}$ of vitamin D per day during the winter months, while 137 children of the same age received placebo [37]. As a result, the prevalence of influenza A infection in the intervention group was significantly lower. Another randomized controlled trial showed that in school children between the ages of 8 and 12 years, the number of parent-reported upper respiratory diseases in the intervention group (intake of $300 \mathrm{IU}$ of vitamin D-enriched milk in the winter months) was significantly lower than that in children without vitamin D supplementation [38].

Another randomized study in 354 children aged 1 to 5 years showed no difference between higher-dose vitamin D supplementation (2000 IU/day) and $400 \mathrm{IU} /$ day vitamin D supplementation for viral upper airway infections during winter months [39]. The authors of a recent Cochrane Review based on four randomized controlled trials on nearly 3200 children in Afghanistan, Spain, and the USA concluded that a protective effect from vitamin D supplementation on pneumonia and diarrhea risk in children up to 5 years age has not been established [40].

Randomized controlled trials did not show any significant or clinically relevant effects of vitamin D on other diseases. A meta-analysis of studies on vitamin D supplementation predominantly in adults found no evidence for a preventative effect on cancer or lifestyle-related diseases [10, 14]. Meta-analyses from randomized controlled trials showed that vitamin D supplementation in arterial hypertension resulted in a small reduction in diastolic blood pressure (by 2 $\mathrm{mmHg}$ ) but not in a reduction in systolic blood pressure [41]. Vitamin D supplements did not result in an improvement in vascular status [42] or cardiovascular performance [43]. While association studies postulate a possible effect of vitamin D supplementation on fasting glucose, HbA1c, and insulin resistance in type II diabetes mellitus [44], randomized controlled trials have shown no influence of vitamin D supplements on the rate of progression from prediabetes to type II diabetes mellitus [45] on the risk of developing type II diabetes mellitus at low vitamin D concentrations [46], glucose-insulin metabolism [47], or insulin resistance in 
children [48]. According to current meta-analysis of randomized controlled trials, in patients with type II diabetes, vitamin D supplementation positively affected HbA1c levels in patients with low vitamin D concentrations [49] or with high dose vitamin D supplements (4000 IU/day) [50].

\section{Conclusions and recommendations}

- During childhood and adolescence, adequate vitamin $\mathrm{D}$ status is desirable to promote enteral calcium absorption and thus bone health.

- In addition to the vitamin D provided in breast milk or infant formula, an oral vitamin D3 supplement (400-500 IU/day) is recommended for all infants in Germany until their second early summer. Depending on the time of their birth, vitamin D supplementation is recommended for a period of one to one and a half years, since during summer, increased ultra violet exposure and vitamin D self-synthesis occurs. A combined supplement comprised of vitamin D and fluoride prophylaxis should be given.

- The total daily intake of vitamin D for premature infants weighing less than $1500 \mathrm{~g}$ at birth is 800 $1000 \mathrm{IU} /$ day in the first few months of life.

- A desirable total vitamin D intake (from sunlightdependent, endogenous synthesis and enteral intake) for children older than 1 year, adolescents, and adults is $600-800 \mathrm{IU} /$ day.

- Regular outdoor activities for children not only improve vitamin D synthesis, but also lead to further positive health effects. Exposure to sunlight improves vitamin D status while exercise increases bone mass development. Exposure to sunlight between April and September, at least twice a week between 10:00 am and 3:00 pm for 5 to $30 \mathrm{~min}$ is the most effective form of improving vitamin D status. Playing outside with an uncovered head, arms, and legs is adequate for vitamin $\mathrm{D}$ production in children and adolescents with skin types II and III. Care should be taken to avoid sunburn.

- Children and adolescents should regularly (once or twice a week) consume fish rich in vitamin D. Fish consumption is desirable for various reasons and contributes to vitamin D intakes.

- There are indications that vitamin D supplementation has possible preventive effects on the risk for infections. However, these effects are not proven beyond doubt.

- Untargeted testing of vitamin D serum concentrations in healthy children without risk factors for vitamin D deficiency is not recommended. Groups at high risk of vitamin D deficiency include children and adolescents with certain chronic diseases and risk factors (Table 2). In these cases, prophylactic vitamin
D supplementation (500-1000 IU/day) may be useful, especially in the winter months.

- A 25-hydroxy-vitamin D serum concentration $(<20$ $\mathrm{ng} / \mathrm{ml}$ ) does not constitute an indication for vitamin D supplementation unless there are additional risk factors (Table 2).

Acknowledgements

We thank Melissa Theurich, Dr. von Hauner Children's Hospital, for her help in preparing the English language version of this manuscript.

Funding

Not applicable

Availability of data and materials

Not applicable

Authors' contributions

All authors contributed equally to this paper. All authors read and approved the final manuscript.

Ethics approval and consent to participate

Not applicable

Consent for publication

Not applicable

\section{Competing interests}

TR received a fee from Novo Nordisk, Pfizer, Serono/Merck, Sandoz/Hexal, Ipsen, and Ferring for consultation and being part of an academic advisory council. He also was paid a fee for lecturing by Novo Nordisk, Pfizer, Serono/Merck, Sandoz/ Hexal, Ipsen, Ferring, and HiPP. The speech for HiPP took place at the Congress for Pediatrics and Adolescent Medicine 2018.

DS has indirect interest by being an executive council of the German Society for Pediatric Endocrinology (DGKED) since 2011 and speaker of the Working Group Bone Metabolism since 2005. He was the leading author of the Guideline

Rachitis Due to a Lack of Vitamin D. The focus of his work is bone metabolism and impaired growth. The key aspect of his clinical work is to be the chief of endocrinology at the Charité Berlin. He was also in charge of training classes from the DGKED and revision course of the German Association of Pediatrics and Adolescent Medicine.

MW received research grants from the German Research Foundation, the German Ministry of Education and Research (BMBF), and Boehringer-Ingelheim-Ulm University BioCenter and from Pfizer and Merck Serono. He also received fees from Nestlé, HiPP, Danone, Milupa, Pfizer, Ipsen, Merck Serono, Abbott, Novo Nordisk, Sandoz, InfectoPharm, Mediagnost, Synlab and consulting fees from Novo Nordisk, Nestlé, Danone, Milupa, and Abbott. He was paid a royalty by Ferring. He got indirect support from InfectoPharm, Nestlé, HiPP, Danone, Ipsen, Merck Serono, Abbott, Novo Nordisk, Sandoz, and Synlab by attending different conferences.

SBDP received a fee for being member of the board from Alexion as well as for lecturing.

$\mathrm{CB}$ received fees for a consultation of the public court, being a member of the board of IQTIG, WidO, and Fresenius. Also, he got paid for lecturing for Chiesi and Nestlé, and his research was financially supported by the German Ministry of Education and Research (BMBF). CB's employer has received fee equivalent payments from the Nestlé Nutrition Institute for CB's presentations. $\mathrm{BH}$ lectured for the Professional Association for Pediatricians (BVKJ) and the German Diabetes Society (DDG) and received a fee. She also received third-party funds from MSD Sharp and Dome.

FJ was a consultant for A\&E, DKG, G-BA, Bundesfachgruppe Neonatology and got third-party funds from the first two named. He was also a member of the board for the Nestlé Nutrition Institute and received third-party funds. For lecturing, he received a fee for Bexter, Fresenius, Humana, Nestlé, and HiPP. For his research, he received third-party funds from Fonterra and Humana.

TK declares no conflict of interest.

AK has received financial grants from Ipsen Pharma.

WM has received grants from Nestlé, Nutricia, and Nutrinia.

CP does not indicate any potential conflicts of interest.

SR does not indicate any potential conflicts of interest. 
BT received grants from Merck Serono, Sandoz, Hexal, PEP e.V., and biomedpark Medien $\mathrm{GmbH}$.

JW received fees for being part of a scientific board from Novo Nordisk and Ipsen as well as for lecturing for FOMF, Pfizer, Novo Nordisk, Merck, Hexal, and Ipsen. PZ received a fee for being in the scientific board of the Deutsche Ärzteblatt. The Ludwig-Maximilians-Universität München and its employee BK were supported by financial support from the Commission of the European Communities (FP5-QLRT-2001-00389 CHOPIN, FP5-QLAM-2001-00582 PIANO, FP6007036QLRT-2001-00389 EARNEST, FP7 -289346- EarlyNutrition), the European Research Council (Grant ERC-2012 AdG - no.322605 META-GROWTH), the European Joint Programming Initiative NutriProgram ERA-HDHL, the European Erasmus + programs Early Nutrition eAcademy Southeast Asia - 573651-EPP -12016-1-EN-EPPKA2-CBHE-JP and Capacity Building to Improve Early Nutrition and Health in South Africa - 598488-EPP-1-2018-1-EN-EPPKA2-CBHE-JP, and the European Interreg- Program Focus in CD - CE111. Additional funding was provided by the Federal Ministry of Education and Research (No. 01 Gl 0825 and INST 409 / 224-1 FUGG), the German Research Foundation (KO912 / 10-1), the McHealth innovation initiative of the LMU and the LMU Center for Advanced Studies. LMU and its employee BK have collaborated with pharmaceutical and dietetic food companies on scientific and educational projects, mostly as part of publicly funded research projects. None of these interactions have affected the content

of this manuscript.

All authors do not declare a conflict of interest under the guidelines of the US Institute of Medicine.

\section{Publisher's Note}

Springer Nature remains neutral with regard to jurisdictional claims in published maps and institutional affiliations.

\section{Author details}

${ }^{1}$ Vestische Kinder- und Jugendklinik Datteln, University Witten/Herdecke, Datteln, Germany. ${ }^{2}$ Sozialpädiatrisches Zentrum für chronisch kranke Kinder, Charité Universitätsmedizin Berlin, Berlin, Germany. ${ }^{3}$ Children's Hospital, University of Ulm, Ulm, Germany. ${ }^{4} \mathrm{LMU}$, Ludwig-Maximilians-Universität München, Dr. von Hauner Children's Hospital, Munich, Germany. ${ }^{5}$ Neonatology, Charité Universitätsmedizin Berlin, Berlin, Germany. ${ }^{6}$ Catholic Children Hospital Wilhelmstift, Hamburg, Pediatric Endocrinology, Clinic Itzehoe, Hamburg, Germany. ${ }^{7}$ Evangelisches Waldkrankenhaus Berlin Spandau, Berlin, Germany. ${ }^{8}$ Ludwigsburg, Germany. ${ }^{9}$ Department of Women's and Children's Medicine, Paediatric Research Center, University of Leipzig, Leipzig, Germany. ${ }^{10}$ Children's Hospital, Heliosklinikum Pforzheim, Pforzheim, Germany. ${ }^{11}$ Institute for Nutritional Sciences, University of Giessen, Giessen, Germany. ${ }^{12}$ Children's Hospital Dresden-Friedrichstadt, Dresden, Germany. ${ }^{13}$ Children's Hospital, University of Bonn, Bonn, Germany. ${ }^{14}$ Children's Hospital, University of Giessen, Giessen, Germany.

\section{Received: 3 April 2019 Accepted: 11 April 2019}

\section{Published online: 06 May 2019}

\section{References}

1. Reinehr T, Schnabel D et al (2018) Vitamin-D-Supplementierung jenseits des zweiten Lebensjahres - Gemeinsame Stellungnahme der Ernährungskommission der Deutschen Gesellschaft für Kinder und Jugendmedizin (DGKJ e.V.) und der Deutschen Gesellschaft für Kinderendokrinologie und Diabetologie (DGKED e.V.). Monatsschr Kinderheilkd 166:814-822 https://doi.org/10.1007/s00112-018-0502-6 [64]

2. Ernährungskommission der Deutschen Gesellschaft für Kinder- und Jugendmedizin (DGKJ) in Zusammenarbeit mit der Arbeitsgemeinschaft Pädiatrische Endokrinologie (Böhles HJ, Fusch C, Genzel-Boroviczény O, Jochum F, Kauth T, Kersting M, Koletzko B (Vorsitzender), Lentze MJ, Moß A (Gast), Mihatsch WA, Przyrembel H, Schnabel D (Gast), Wabitsch M): VitaminD-Versorgung im Säuglings-, Kindes- und Jugendalter. Monatschrift für Kinderheilkunde 2011;160(11):1163-1166

3. Wabitsch M, Koletzko B, Schnabel D, Moss A: Vitamin D-Versorgung im Säuglings-, Kindes- und Jugendalter; available from: http://www.dgkj.de/ wissenschaft/stellungnahmen/meldung/meldungsdetail/vitamin_d_ versorgung_im_saeuglings_kindes_und_jugendalter/

4. Munns CF, Shaw N, Kiely M, Specker BL, Thacher TD, Ozono K et al (2016) Global consensus recommendations on prevention and management of nutritional rickets. J Clin Endocrinol Metab 101(2):394-415
5. Bührer C, Genzel-Broviczeny O, Jochum F, Kauth T, Kersting M, Koletzko B, et al. Ernährung gesunder Säuglinge. Monats Kinderheilkund 2014;527-538

6. Grossman Z, Hadjipanayis A, Stiris T, Del TS, Mercier JC, Valiulis A et al (2017) Vitamin D in European children-statement from the European Academy of Paediatrics (EAP). Eur J Pediatr 176(6):829-831

7. Bös K, Schmidt S, Bergmann K, Lämmle L, Koletzko B (2012) Einflussfaktoren auf die Vitamin-D-Versorgung deutscher Kinder und Jugendlicher. Ernährungs Umschau 09:496-503

8. Hintzpeter B, Scheidt-Nave C, Muller MJ, Schenk L, Mensink GB (2008) Higher prevalence of vitamin $D$ deficiency is associated with immigrant background among children and adolescents in Germany. J Nutr 138(8):1482-1490

9. Farrar MD, Mughal MZ, Adams JE, Wilkinson J, Berry JL, Edwards L et al (2016) Sun exposure behavior, seasonal vitamin $D$ deficiency, and relationship to bone health in adolescents. J Clin Endocrinol Metab 101(8):3105-3113

10. Deutsche Gesellschaft für Ernährung. Empfehlung zu Vitamin D. www dge de/wissenschaft/referenzwerte/vitamin-d/ Available from: http://www.dge. de/wissenschaft/referenzwerte/vitamin-d/

11. Theodoratou E, Tzoulaki I, Zgaga L, loannidis JP (2014) Vitamin D and multiple health outcomes: umbrella review of systematic reviews and metaanalyses of observational studies and randomised trials. BMJ 348:92035

12. Grober U, Spitz J, Reichrath J, Kisters K, Holick MF, Vitamin D (2013) Update 2013: from rickets prophylaxis to general preventive healthcare. Dermatoendocrinol 5(3):331-347

13. Bouillon $R$, Verlinden $L$ (2014) Does a better vitamin $D$ status help to reduce cardiovascular risks and events? Endocrine 47(3):662-663

14. Manson JE, Brannon PM, Rosen CJ, Taylor CL (2016) Vitamin D deficiency - is there really a pandemic? N Engl J Med 375(19):1817-1820

15. Bolland MJ, Grey A, Gamble GD, Reid IR (2014) The effect of vitamin D supplementation on skeletal, vascular, or cancer outcomes: a trial sequential meta-analysis. Lancet Diabetes Endocrinol 2(4):307-320

16. Gil AJ, Plaza-Diaz J, Mesa MD (2018) Vitamin D: classic and novel actions. Ann Nutr Metab 72(2):87-95 in press

17. Wang Y, Zhu J, DeLuca HF (2012) Where is the vitamin D receptor? Arch Biochem Biophys 523(1):123-133

18. Hewison M (1992) Vitamin D and the immune system. J Endocrinol 132(2):173-175

19. Zittermann A, Pilz S, Hoffmann H, Marz W (2016) Vitamin D and airway infections: a European perspective. Eur J Med Res 21:14

20. Hollis BW (2010) Assessment and interpretation of circulating 25hydroxyvitamin $D$ and 1,25-dihydroxyvitamin $D$ in the clinical environment. Endocrinol Metab Clin North Am 39(2):271-286 table

21. Binkley N, Dawson-Hughes B, Durazo-Arvizu R, Thamm M, Tian L, Merkel JM et al (2017) Vitamin D measurement standardization: the way out of the chaos. J Steroid Biochem Mol Biol 173:117-121

22. Heaney RP (2008) Vitamin D and calcium interactions: functional outcomes. Am J Clin Nutr 88(2):541S-544S

23. Institute of Medicine (US) Committee to Review Dietary Reference Intakes for Vitamin D and Calcium; Editors: Ross AC, Taylor CL, Yaktine AL, Del Valle HB (2011) Dietary Reference Intakes for Calcium and Vitamin D. Washington (DC): National Academies Press (US);

24. King JC, Garza C (2007) Harmonization of nutrient intake values. Food Nutr Bull 28(1 Suppl International):S3-S12

25. Koletzko B, Bhatia J, Bhutta Z, Cooper P, Makrides M, Uauy R, Wang W (2015) Pediatric Nutrition in Practice. 2nd. revised edition. Basel, Karger, p 1-326 (ISBN 0084-2230)

26. Hill TR, Cotter AA, Mitchell S, Boreham CA, Dubitzky W, Murray L et al (2008) Vitamin $D$ status and its determinants in adolescents from the Northern Ireland Young Hearts 2000 cohort. Br J Nutr 99(5):1061-1067

27. Carson EL, Pourshahidi LK, Hill TR, Cashman KD, Strain JJ, Boreham CA et al (2015) Vitamin D, muscle function, and cardiorespiratory fitness in adolescents from the young hearts study. J Clin Endocrinol Metab 100(12):4621-4628

28. Lehtonen-Veromaa MK, Mottonen TT, Nuotio IO, Irjala KM, Leino AE, Viikari JS (2002) Vitamin D and attainment of peak bone mass among peripubertal Finnish girls: a 3-y prospective study. Am J Clin Nutr 76(6):1446-1453

29. Lehtonen-Veromaa M, Mottonen T, Irjala K, Nuotio I, Leino A, Viikari J (2000) A 1-year prospective study on the relationship between physical activity, markers of bone metabolism, and bone acquisition in peripubertal girls. J Clin Endocrinol Metab 85(10):3726-3732

30. Viljakainen HT, Natri AM, Karkkainen M, Huttunen MM, Palssa A, Jakobsen J et al (2006) A positive dose-response effect of vitamin D supplementation on site-specific bone mineral augmentation in adolescent girls: a double- 
blinded randomized placebo-controlled 1-year intervention. J Bone Miner Res 21(6):836-844

31. Winzenberg T, Powell S, Shaw KA, Jones G (2011) Effects of vitamin D supplementation on bone density in healthy children: systematic review and meta-analysis. BMJ 342:C7254

32. Winzenberg TM, Powell S, Shaw KA, Jones G (2010) Vitamin D supplementation for improving bone mineral density in children. Cochrane Database Syst Rev 10:CD006944

33. Hypponen E, Laara E, Reunanen A, Jarvelin MR, Virtanen SM (2001) Intake of vitamin D and risk of type 1 diabetes: a birth-cohort study. Lancet 358(9292): $1500-1503$

34. Harjutsalo V, Sund R, Knip M, Groop PH (2013) Incidence of type 1 diabetes in Finland. JAMA 310(4):427-428

35. Zipitis CS, Akobeng AK (2008) Vitamin D supplementation in early childhood and risk of type 1 diabetes: a systematic review and metaanalysis. Arch Dis Child 93(6):512-517

36. Makinen M, Mykkanen J, Koskinen M, Simell V, Veijola R, Hyoty H et al (2016) Serum 25-hydroxyvitamin $\mathrm{D}$ concentrations in children progressing to autoimmunity and clinical type 1 diabetes. J Clin Endocrinol Metab 101(2):723-729

37. Martineau $A R$, Cates $C J$, Urashima $M$, Jensen $M$, Griffiths $A P$, Nurmatov $U$ et al (2016) Vitamin D for the management of asthma. Cochrane Database Syst Rev 9: CD011511

38. Urashima M, Segawa T, Okazaki M, Kurihara M, Wada Y, Ida H (2010) Randomized trial of vitamin $D$ supplementation to prevent seasonal influenza A in schoolchildren. Am J Clin Nutr 91(5):1255-1260

39. Camargo CA Jr, Ganmaa D, Frazier AL, Kirchberg FF, Stuart JJ, Kleinman K et al (2012) Randomized trial of vitamin D supplementation and risk of acute respiratory infection in Mongolia. Pediatrics 130(3):e561-e567

40. Aglipay M, Birken CS, Parkin PC, Loeb MB, Thorpe $K$, Chen Y et al (2017) Effect of high-dose vs standard-dose wintertime vitamin $D$ supplementation on viral upper respiratory tract infections in young healthy children. JAMA 318(3):245-254

41. Yakoob MY, Salam RA, Khan FR, Bhutta ZA (2016) Vitamin D supplementation for preventing infections in children under five years of age. Cochrane Database Syst Rev 11:CD008824

42. Witham MD, Nadir MA, Struthers AD (2009) Effect of vitamin D on blood pressure: a systematic review and meta-analysis. J Hypertens 27(10):1948-1954

43. de Vries MA, van der Meulen N, van de Geijn GM, Klop B, van der Zwan EM, Prinzen $L$ et al (2016) Effect of a single dose vitamin D3 on postprandial arterial stiffness and inflammation in vitamin D deficient women. J Clin Endocrinol Metab 22:jc20163394

44. Wang L, Song Y, Manson JE, Pilz S, Marz W, Michaelsson K et al (2012) Circulating 25-hydroxy-vitamin $D$ and risk of cardiovascular disease: a metaanalysis of prospective studies. Circ Cardiovasc Qual Outcomes 5(6):819-829

45. Kelly A, Brooks LJ, Dougherty S, Carlow DC, Zemel BS (2011) A crosssectional study of vitamin $D$ and insulin resistance in children. Arch Dis Child 96(5):447-452

46. Jorde R, Sollid ST, Svartberg J, Schirmer H, Joakimsen RM, Njolstad I et al (2016) Vitamin D 20,000 IU per week for five years does not prevent progression from prediabetes to diabetes. J Clin Endocrinol Metab 101(4):1647-1655

47. Mousa A, Naderpoor N, de Court TH, Kellow N, Walker K et al (2017) Vitamin D supplementation has no effect on insulin sensitivity or secretion in vitamin D-deficient, overweight or obese adults: a randomized placebocontrolled trial. Am J Clin Nutr 105(6):1372-1381

48. Seida JC, Mitri J, Colmers IN, Majumdar SR, Davidson MB, Edwards AL et al (2014) Clinical review: effect of vitamin D3 supplementation on improving glucose homeostasis and preventing diabetes: a systematic review and meta-analysis. J Clin Endocrinol Metab 99(10):3551-3560

49. Ferira AJ, Laing EM, Hausman DB, Hall DB, McCabe GP, Martin BR et al (2016) Vitamin D supplementation does not impact insulin resistance in black and white children. J Clin Endocrinol Metab 101(4):1710-1718

50. Wu C, Qiu S, Zhu X, Li L (2017) Vitamin D supplementation and glycemic control in type 2 diabetes patients: a systematic review and meta-analysis. Metabolism 73:67-76

51. Mirhosseini N, Vatanparast H, Mazidi M, Kimball SM (2017) The effect of improved serum 25-hydroxyvitamin D status on glycemic control in diabetic patients: a meta-analysis. J Clin Endocrinol Metab 102(9):3097-3110

52. Martineau AR, Jolliffe DA, Hooper RL, Greenberg L, Aloia JF, Bergman P et al (2017) Vitamin D supplementation to prevent acute respiratory tract infections: systematic review and meta-analysis of individual participant data. BMJ 15(356): 6583
53. Kim YR, Seo SC, Yoo Y, Choung JT (2017) Are children with asthma in South Korea also associated with vitamin D deficiency? Environ Health Toxicol 32: e2017005

54. Esfandiar N, Alaei F, Fallah S, Babaie D, Sedghi N (2016) Vitamin D deficiency and its impact on asthma severity in asthmatic children. Ital J Pediatr 42(1):108

55. Meyer T, Becker A, Sundermann J, Rothenberger A, Herrmann-Lingen C (2017) Attention deficit-hyperactivity disorder is associated with reduced blood pressure and serum vitamin D levels: results from the nationwide German Health Interview and Examination Survey for Children and Adolescents (KiGGS). Eur Child Adolesc Psychiatry 26(2):165-175

56. Avcil S, Uysal P, Yilmaz M, Erge D, Demirkaya SK, Eren E, Vitamin D (2017) Deficiency and a blunted parathyroid hormone response in children with attention-deficit/hyperactivity disorder. Clin Lab 63(3):435-443

57. Mohammadpour N, Jazayeri S, Tehrani-Doost M, Djalali M, Hosseini M, Effatpanah M et al (2016) Effect of vitamin D supplementation as adjunctive therapy to methylphenidate on ADHD symptoms: a randomized, double blind, placebo-controlled trial. Nutr Neurosci 7:1-8

58. Reinehr T, de SG AU, Kersting M, Andler W (2007) Vitamin D status and parathyroid hormone in obese children before and after weight loss. Eur J Endocrinol 157(2):225-232

59. Saneei P, Salehi-Abargouei A, Esmaillzadeh A (2013) Serum 25-hydroxy vitamin $D$ levels in relation to body mass index: a systematic review and meta-analysis. Obes Rev 14(5):393-404

60. Wortsman J, Matsuoka LY, Chen TC, Lu Z, Holick MF (2000) Decreased bioavailability of vitamin D in obesity. Am J Clin Nutr 72(3):690-693

61. Jagannath VA, Fedorowicz Z, Asokan GV, Robak EW, Whamond L (2010) Vitamin $D$ for the management of multiple sclerosis. Cochrane Database Syst Rev 8(12):CD008422

62. Kampman MT, Steffensen LH, Mellgren SI, Jorgensen L (2012) Effect of vitamin D3 supplementation on relapses, disease progression, and measures of function in persons with multiple sclerosis: exploratory outcomes from a double-blind randomised controlled trial. Mult Scler 18(8):1144-1151

63. Soilu-Hanninen M, Aivo J, Lindstrom BM, Elovaara I, Sumelahti ML, Farkkila M et al (2012) A randomised, double blind, placebo controlled trial with vitamin D3 as an add on treatment to interferon beta-1b in patients with multiple sclerosis. J Neurol Neurosurg Psychiatry 83(5):565-571

\section{Submit your manuscript to a SpringerOpen ${ }^{\circ}$ journal and benefit from:}

- Convenient online submission

- Rigorous peer review

- Open access: articles freely available online

High visibility within the field

- Retaining the copyright to your article

Submit your next manuscript at $\boldsymbol{\nabla}$ springeropen.com 